University of Montana

ScholarWorks at University of Montana

\title{
Reproductive Success of Chestnut-Collared Longspurs in Native and Exotic Grassland
}

J. D. Lloyd

Thomas E. Martin

University of Montana - Missoula, tom.martin@umontana.edu

Follow this and additional works at: https://scholarworks.umt.edu/wildbio_pubs

Part of the Life Sciences Commons

Let us know how access to this document benefits you.

\section{Recommended Citation}

Lloyd, J. D. and Martin, Thomas E., "Reproductive Success of Chestnut-Collared Longspurs in Native and Exotic Grassland" (2005). Wildlife Biology Faculty Publications. 38.

https://scholarworks.umt.edu/wildbio_pubs/38

This Article is brought to you for free and open access by the Wildlife Biology at ScholarWorks at University of Montana. It has been accepted for inclusion in Wildlife Biology Faculty Publications by an authorized administrator of ScholarWorks at University of Montana. For more information, please contact scholarworks@mso.umt.edu. 


\title{
REPRODUCTIVE SUCCESS OF CHESTNUT-COLLARED LONGSPURS IN NATIVE AND EXOTIC GRASSLAND
}

\author{
John D. Lloyd ${ }^{1}$ And Thomas E. Martin \\ Montana Cooperative Wildlife Research Unit, University of Montana, Missoula, MT
}

\begin{abstract}
Habitat loss and fragmentation have been identified as important factors in the decline of grassland bird populations. However, population declines are apparent even in prairie ecosystems that remain relatively intact suggesting that additional factors are involved. The degradation of breeding habitat may be one such factor, but few studies have examined habitatspecific demography of grassland birds, and thus little is known of how changes in breeding habitat may be related to population declines. We addressed this question by comparing reproductive success of Chestnut-collared Longspurs (Calcarius ornatus) in patches of native prairie and in monocultures of crested wheatgrass (Agropyron cristatum), a grass introduced from Asia. Using recently developed methods for estimating nest survival rate, we found that, independent of habitat type, daily nest survival generally declined from egg laying to fledging. We also found a positive effect of clutch size on nest survival rate, which we interpreted as evidence for individual heterogeneity in nest survival. Finally, we found that the odds of a nest surviving a given day were $17 \%$ lower in the exotic habitat, and that nestlings grew more slowly, and had a smaller final mass in the exotic habitat. Despite having lower reproductive success in the exotic habitat, we found no evidence that Chestnut-collared Longspurs preferred to nest in the native habitat. Our results show that the introduction and spread of a commonly planted exotic grass has adverse fitness consequences for a grassland bird, and highlight the importance of maintaining native prairie.
\end{abstract}

Key words: Calcarius ornatus, Chestnut-collared Longspur, Conservation Reserve Program, crested wheatgrass, exotic plant, grassland bird, nest success.

\section{Éxito Reproductivo de Calcarius ornatus en Praderas Nativas y Exóticas}

Resumen. La pérdida y fragmentación de hábitat han sido identificados como factores importantes con respecto a la disminución de las poblaciones de aves de pastizales. Sin embargo, las poblaciones están en disminución aún en ecosistemas de pradera relativamente intactos, lo que sugiere que otros factores están involucrados en el proceso. La degradación del hábitat de nidificación podría ser uno de estos factores adicionales, pero pocos estudios han examinado la demografía de aves de pastizales en distintos hábitats. En consecuencia, se conoce muy poco acerca de cómo los cambios en el hábitat podrían estar relacionados con las disminuciones poblacionales. En este estudio abordamos esta pregunta comparando el éxito reproductivo de individuos de la especie Calcarius ornatus en parches de praderas nativas y en monocultivos de Agropyron cristatum, un pasto introducido de Asia. Empleando métodos recientemente desarrollados para estimar la tasa de supervivencia de los nidos, encontramos que independientemente del tipo de hábitat, la supervivencia diaria de los nidos en general disminuyó desde la puesta hasta el momento de emplumamiento de los pichones. También encontramos un efecto positivo del tamaño de la nidada sobre la tasa de supervivencia de los nidos, el cual interpretamos como evidencia de que existe heterogeneidad individual en la supervivencia de los nidos. Finalmente, encontramos que en el ambiente exótico la probabilidad de sobrevivir de un nido durante un día dado fue un $17 \%$ menor, los pichones crecieron más lentamente y presentaron una masa final menor. A pesar de presentar un éxito reproductivo menor en el ambiente exótico, no encontramos evidencia de que las aves prefirieran nidificar en el ambiente nativo. Nuestros resultados muestran que la introducción y propagación de un pasto exótico que es plantado con frecuencia tiene efectos adversos sobre la adecuación de un ave de pastizal, y resaltan la importancia de mantener las praderas nativas.

\section{INTRODUCTION}

Population declines of North American grassland birds are now well documented (Knopf

Manuscript received 7 September 2004; accepted 11 January 2005.

${ }^{1}$ Present address: Ecostudies Institute, 22345 S. Poplar Rd., Estacada, OR 97023. E-mail: jlloyd@ecoinst.org
1994, Peterjohn and Sauer 1999, Vickery and Herkert 2001), and several likely causes have been identified. The loss and fragmentation of breeding habitat has clearly played a role in the decline of some species (Johnson and Temple 1990, Herkert 1994, Winter and Faaborg 1999, Winter et al. 2000, Herkert et al. 2003). However, most research on the causes of population 
declines among grassland birds has focused on tallgrass prairie, which has suffered far greater losses than other prairie ecosystems. For example, $<10 \%$ of tallgrass prairie is estimated to remain (Noss et al. 1995), whereas the mixed- and shortgrass prairies that form the core of North America's grasslands cover $60 \%$ to more than $80 \%$ of their original area (Klopatek et al. 1979, Bragg and Steuter 1995). Yet population declines are evident for bird species throughout the prairie region, suggesting that, in addition to habitat loss and fragmentation, other factors are involved in the decline of grassland bird populations.

Degradation of breeding habitat may be related to the decline of grassland birds, but few studies have examined habitat-specific demography, and thus little is known of how changes in breeding habitat may affect population growth rate. However, even in regions where prairie ecosystems remain relatively intact, breeding habitat for grassland birds has been extensively altered by unnatural disturbance regimes and the introduction and spread of exotic plants (Bragg and Steuter 1995, Lesica and DeLuca 1996). Altered disturbance regimes are known to affect habitat quality for grassland birds (Kantrud 1981, Pylypec 1991, Madden et al. 1999, Madden et al. 2000), but far less is known about the effect of exotic plants on habitat quality for grassland birds (but see Pampush and Anthony 1993, Mermoz and Reboreda 1998).

The abundance of some grassland bird species is lower in habitats dominated by exotic plants (Wilson and Belcher 1989, Scheiman et al. 2003), suggesting that the spread of exotic plants into native prairie may reduce habitat quality. Yet correlations based on the presence or abundance of a species may misrepresent the suitability of habitats (Van Horne 1983, Martin 1992a). Instead, components of fitness must be measured if we are to understand how exotic plants affect habitat quality for grassland birds. This is not a trivial question given the degree to which exotic vegetation has spread throughout the North American prairie region; for example, crested wheatgrass (Agropyron cristatum), an Asian grass introduced throughout western North American, covered an estimated six to ten million hectares within the Great Plains as of 1996 (Lesica and Deluca 1996). This is likely an underestimate of the current extent of this species, given that crested wheatgrass continues to be planted as part of the Conservation Reserve Program (CRP), for erosion control, and to improve forage for livestock (Byers 2004).

Here, we seek to address this information gap by providing a comparison of reproductive success for a passerine bird breeding in native prairie and exotic grassland within the mixed-grass prairie of the United States. Using recently developed methods for modeling avian nest survival (Shaffer 2004, Peak et al. 2004), we provide comparisons of nest success for a single common species, the Chestnut-collared Longspur (Calcarius ornatus; hereafter longspurs), in native mixed-grass prairie and monocultures of introduced crested wheatgrass. Like most of the birds of this region, population numbers of longspurs have experienced pronounced downward trends as measured by the Breeding Bird Survey (Peterjohn and Sauer 1999). We also provide data on nestling growth rate, which typically covaries with habitat quality (Merila and Fry 1998, McCarty and Winkler 1999, Kunz and Ekman 2000) and is an important component of fitness in altricial birds (Gebhardt-Henrich and Richner 1998). In addition to estimating habitat-specific reproductive success, we also evaluate habitat preferences by comparing settlement patterns and density of nesting pairs in both habitat types. Data on habitat preferences and habitatspecific vital rates are critical in understanding the link between exotic plants, habitat degradation, and the decline of grassland bird populations, and are also essential in providing land managers information on how best to manage our remaining grasslands.

\section{METHODS}

\section{STUDY AREA AND STUDY PLOTS}

Our study was conducted from 2001-2002 at Medicine Lake National Wildlife Refuge $\left(48^{\circ} 30^{\prime} \mathrm{N}, 104^{\circ} 17^{\prime} \mathrm{W}\right)$, located on the glaciated plains north of the Missouri River in eastern Montana. In 2001, we established study plots in three monocultures of crested wheatgrass and three patches of native, mixed-grass prairie. To verify expected vegetation differences among native and exotic plots, we visually estimated the percent cover of different plant species in 35 5-m radius sampling locations, randomly distributed on each plot. One study plot in each habitat was $25 \mathrm{ha}$, and the remaining two plots in each habitat were 12.5 ha. To reduce variation among 
plots, minimize the effect of potentially confounding variables, and to isolate the effect of habitat type on longspur reproductive success, we selected fields non-randomly based on history of disturbance (no grazing or burning within the previous three years) and uniformity of vegetation (i.e., plots in exotic habitat consisted of pure monocultures of crested wheatgrass, and plots in native habitat were free of exotic plants). Furthermore, to control for differences that arise as monocultures of crested wheatgrass age (Christian and Wilson 1999), all of our crested wheatgrass plots were placed in fields that had been stable monocultures since they were planted in the 1940s and 1950s. Although we do not know the history of the study plots prior to 1940 , all of the plots were similar in climate, landscape context, topography, soil type (Richardson and Hanson 1977), and aspect. Thus, we believe that any differences in longspur reproductive success or habitat preference between the native and exotic plots can be reasonably ascribed to differences in the dominant plant communities. Because all of our plots were established within larger fields of the same vegetation type, each plot was buffered from other habitat types by at least $150 \mathrm{~m}$. Despite the presence of the buffer, nests located on or outside the boundaries of a plot were censored from analysis.

\section{SETTLEMENT PATTERNS}

In 2002 , to determine whether male longspurs exhibited a preference for either habitat, we examined settlement patterns by systematically surveying each plot for territorial males. Male longspurs began arriving at the study site on 9 April, but remained in migratory flocks for several weeks as females arrived (see also Hill and Gould 1993). Beginning on 24 April, when migratory flocks began to disintegrate, a single observer walked slowly along flagged grid lines that covered each plot until a singing male was encountered. Male longspurs sing as part of an aerial display (Hill and Gould 1993) and are thus quite conspicuous and easily detected in the flat, open terrain of our study site. When a singing male was encountered, the observer recorded his behavior and movements (relative to the flagged grid) for $10 \mathrm{~min}$. Males were assumed to be defending territories if they were observed making multiple displays within $50 \mathrm{~m}$ (longspurs rarely defend territories $>1$ ha, Hill and Gould 1993) of their original location during the 10-min observation period. We also assumed that males were defending territories if they were observed to engage in aggressive interactions (aerial fights or chases, Hill and Gould 1993) with other males during the observation period. Males that sang only once, or that left the area during the observation period, were not considered to be defending a territory. By establishing stringent criteria for determining territoriality, we also lessened the risk of counting individual males more than once during a survey period. Each plot was surveyed every three days until 12 May, at which point most birds appeared to have settled on a territory and were beginning to nest.

\section{NESTING DENSITY \\ AND REPRODUCTIVE SUCCESS}

To examine patterns of reproductive success, we located and monitored nests throughout the 2001 and 2002 breeding seasons. We located nests using both systematic searches and behavioral observations of adult longspurs. During systematic searches, we flushed adults off of the nest by dragging a weighted rope across each plot. To minimize the chances of encountering unattended nests, which are not detected by this method, we conducted systematic searches from 10:0014:00, a period during which nest attendance is high (JDL, unpubl. data). Each plot was searched three times between mid May and late June of each year (2001: 18 May-30 June, 2002: 18 May-27 June).

To supplement systematic searches, we conducted nest searches using behavioral cues provided by adults. An observer spent approximately six hours per day on a single study plot searching for nests. Each plot was searched for nests twice a week from 20 May-22 July, excluding days on which systematic searches were conducted. By intensively searching plots throughout the breeding season, and by holding search effort constant between habitats, we attempted to minimize any bias in comparisons of reproductive success and nest density arising from differential sampling of nests in native and exotic habitat. Because longspurs generally make multiple nesting attempt per year (Hill and Gould 1993), the total number of nests per unit area will tend to overestimate the density of nesting pairs on a plot. Furthermore, differences in renesting rate between habitats might confound comparisons of nesting density in native 
and exotic habitat. To avoid these problems, we only used data from nests believed to be the first nests of the season to estimate the density of nesting pairs. Using the phenology of nesting attempts as a guide, we assumed that all nests initiated prior to 1 June were first nests. Based on the bimodal pattern of nest initiation (Fig. 1), the peaks of which likely reflect first and second nesting attempts, we believe this assumption is reasonable. In all other comparisons, we used data from all nesting attempts.

We marked the location of each nest with one or two small pieces of flagging placed 1-2 m from the nest cup. Flagging may or may not increase the risk of nest predation (Gotmark 1992, Hein and Hein 1996), but was used in the same way in both habitats and thus is unlikely to bias comparisons of reproductive success. For nests found during laying, age could be determined with a high degree of certainty, as longspurs lay one egg per day, usually early in the morning (Hill and Gould 1993). The age of nests found during incubation was estimated using candlers (Lokemoen and Koford 1996), and nests containing nestlings were aged based on the mass, tarsus length, and feather development of the young.

To determine the fate of nests we returned every two to three days to inspect the contents except when hatching or fledging was expected, at which point we visited daily. Nests that fledged at least one young were considered successful. If the nest was empty prior to the expected fledging date, we searched the territory for adults to determine if they were feeding fledglings. Parents continue to feed and defend fledglings on the territory for several weeks after the young leave the nest (Hill and Gould 1993); thus, we assumed that predation had occurred if we were unable to locate adults feeding fledglings after nestlings had disappeared from the nest. Our morphological measurements of nestlings gave us a third way to assess the fate of nests. Among nestlings of known fate, no individual with a body mass of $<10 \mathrm{~g}$ on or after day 7 of the nestling period successfully fledged; thus, we used the mass of nestlings at the last nest check to determine nest fate.

\section{NESTLING GROWTH RATE}

Nestling growth rate was measured as an additional component of reproductive success. In altricial birds, growth rate is an important com- ponent of fitness because it affects the duration of the nestling period, the probability that young survive to fledge, and future prospects for survival and reproduction (Gebhardt-Henrich and Richner 1998). Nestlings were individually marked with a felt-tipped pen as they hatched, and their mass was estimated every two days using a portable electronic balance (Acculab, Edgewood, NY). The last measurement taken prior to fledging was used as an index of mass at fledging. In 2002, we also measured the length of both tarsi and the total length of the outermost primaries (including shaft). Mass was estimated to the nearest $0.1 \mathrm{~g}$ and tarsus and primary feather length to the nearest $0.1 \mathrm{~mm}$.

\section{STATISTICAL ANALYSES}

We estimated daily nest survival (probability that a nest survives a given day) and tested hypotheses about the causes of variation in daily nest survival using the generalized linear modeling approach of Shaffer (2004). Logistic-exposure models were fit using PROC GENMOD (SAS Institute 1999), a binomial response distribution, and the link function defined by Shaffer (2004). Prior to analysis, we developed a set of candidate models (Anderson and Burnham 1998) that reflected our assessment of likely causes of variation in nest survival. In building our set of candidate models, we included the following variables that we considered potentially important in explaining variation in nest success.

Habitat. Habitat was defined as native versus exotic grassland.

Year. We modeled year effects because annual variation in nest survival is common (Greenwood et al. 1995), although the causes are often unknown.

Nest age. Nest survival rate can also vary as a function of nest age (Ricklefs 1969). Predators may use parental activity as a cue for locating nests, and as a result daily nest survival may decline from incubation to fledging as parents make more trips to the nest to provide food for their young (Skutch 1949, Martin et al. 2000). However, the effect of parental activity may be confounded by nest-site quality, such that poorly-concealed nests are depredated quickly yielding an apparently inverse relationship between nest age and daily survival (Martin and Roper 1988, Martin et al. 2000). We considered only a linear effect of age, as preliminary models with more complex functions did not converge. 
Temporal variation within season. Most birds in seasonal environments exhibit a seasonal decline in reproductive success (Nilsson 1989, Hochachka 1990), so we also included a linear time trend in daily nest survival in our model set.

Clutch size. Clutch size, like nest age, may be related to nest survival rate in two opposing ways. First, nests with more young may incur increased rates of predation because larger broods are more conspicuous to predators (Skutch 1949, Lima 1987, Martin 1992b). Alternatively, if intraspecific variation in clutch size reflects variation in female condition or quality, with birds in poor condition or of low quality laying fewer eggs (Slagsvold and Lifjeld 1988, Price and Liou 1989), then daily nest survival may increase with clutch size. This effect could arise, for instance, due to a correlation between clutch size and nest-site selection: less experienced females, females in poor condition, or females of low quality may produce small clutches and choose inappropriate nest sites that are at greater risk of detection by predators.

We evaluated a candidate set of 15 a priori models, based on combinations of the above variables, that we believed could reasonably explain variation in nest survival. Using the output from PROC GENMOD, we evaluated the degree of support for each model using Akaike's Information Criterion (AIC; Akaike 1973). The best model was selected by judging the degree of support as measured by $\mathrm{AIC}_{c}$ (AIC corrected for small sample size; Burnham and Anderson 1998) and normalized Akaike weights. Models with $\Delta \mathrm{AIC}_{c} \leq 2$ were considered to have substantial support whereas models with $\Delta \mathrm{AIC}_{c} \geq$ 4 were considered to have little to no empirical support (Burnham and Anderson 2001). Goodness-of-fit of the global model was evaluated using the decile method of Hosmer and Lemeshow (1989).

We interpreted the strength of each variable by using odds ratios calculated from model-averaged coefficients and 95\% confidence intervals based on unconditional standard errors (Burnham and Anderson 1998). Using model-averaged estimates allowed us to incorporate modelselection uncertainty and provided a more robust indication of the effect of each variable on daily nest survival (Anderson et al. 2000). We chose to use odds ratios to examine the strength of each variable because they are widely used in logistic regression and are a useful measure of the size of an effect. Nonetheless, the interpretation of odds ratios is not always intuitive. Odds are not synonymous with probability or risk, although they are often interpreted as such (Davies et al. 1998). The odds of nest failure, for example, are calculated as the number of nests that fail divided by the number of nests that survive; on the other hand, the probability of nest failure is calculated as the number of nests that fail divided by the total number of nests under observation. This subtle difference has important implications for interpretation. Suppose that a one-unit change in a predictor variable increases the probability of nest failure from $50 \%$ to $66 \%$. Although the probability has not doubled $(+16 \%)$, the odds ratio of nest failure (ratio of number failed to number survived) has increased from 1 to 2 . Thus, it is critical to note the difference between the odds of an event and the likelihood or probability of the event. Percentage change in the odds of nest survival for each one-unit change in an independent variable was calculated by subtracting 1 from the odds ratio and multiplying this value by 100 . Except where noted, we do not interpret odds ratios with confidence intervals overlapping one.

Nestling growth rates for each trait were analyzed by using non-linear regression to fit a logistic growth curve to the entire data set. Differences in growth between habitats were examined by comparing residuals from the nonlinear regression using ANOVA (Ricklefs 1983). To avoid artificially inflating error degrees of freedom, residuals from the growth curve were first pooled among nestlings within a nest, then among nests within a plot, and finally among plots within a habitat. Basing the analysis on residuals allowed us to include all measured individuals in the analysis; had we attempted to estimate growth parameters for each individual or nest we would have been forced to exclude a large number of samples.

Values are presented as means with $95 \%$ upper and lower confidence limits and we used $\alpha$ $=0.05$ as the level of statistical significance.

\section{RESULTS}

\section{VEGETATION DIFFERENCES BETWEEN HABITATS}

Native and exotic plots were similar in the percentage of ground covered by living vegetation (native: $49 \%, \mathrm{CL}=45 \%, 53 \%$; exotic: $49 \%$, CL $=46 \%, 53 \%)$. Exotic plots had a greater mean 


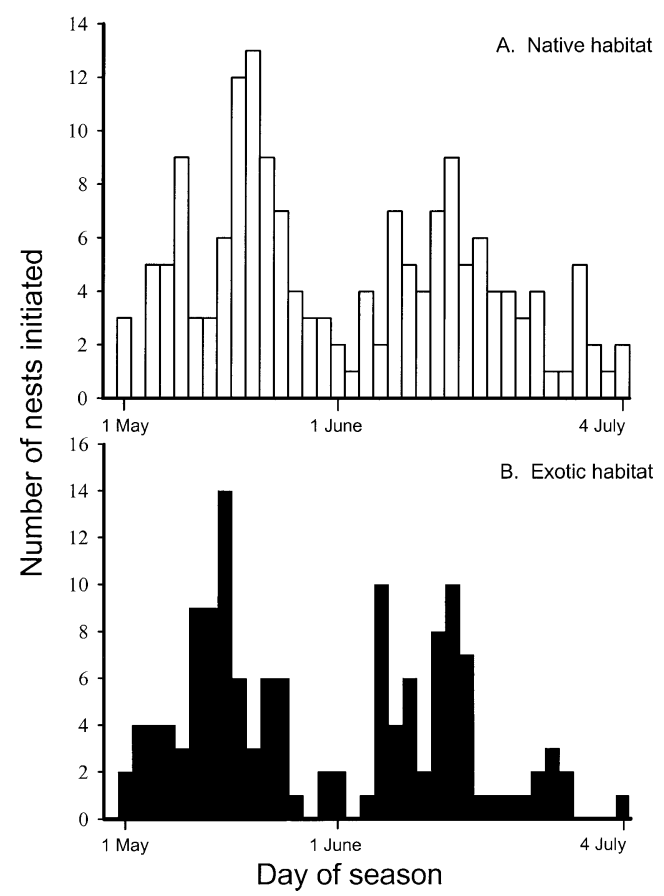

FIGURE 1. Number of nests initiated by Chestnutcollared Longspurs in (A) native habitat and (B) exotic habitat at Medicine Lake National Wildlife Refuge, Montana, 2001-2002.

percentage of ground covered by standing dead vegetation (native: $39 \%, \mathrm{CL}=36 \%, 41 \%$; exotic: $47 \%, \mathrm{CL}=43 \%, 52 \%)$ and had less bare ground (native: $14 \%, \mathrm{CL}=10 \%, 17 \%$; exotic: $4 \%, \mathrm{CL}=2 \%, 5 \%$ ). Native and exotic plots also differed in plant species composition. As expected, crested wheatgrass dominated plots in the exotic habitat with a mean cover of $99 \%$ (CL $=98 \%, 100 \%$ ). Fringed sagewort (Artemesia frigida) was the only other species recorded at more than one point, and accounted for $1 \%$ cover $(\mathrm{CL}=0 \%, 2 \%)$ in the exotic habitat. In contrast, plots in the native habitat were dominated by a mix of species including: porcupinegrass (Stipa spp.; 38\%, CL $=34 \%, 42 \%$ ), junegrass (Koeleria cristata; $20 \%, \mathrm{CL}=17 \%, 23 \%$ ), clubmoss (Selaginella sp.; $10 \%, \mathrm{CL}=5 \%, 15 \%$ ), western wheatgrass (Agropyron smithii; 10\%, $\mathrm{CL}=8 \%, 12 \%$ ), blue grama (Bouteloua gracilis; $6 \%, \mathrm{CL}=5 \%, 7 \%)$, fringed sagewort $(5 \%$, $\mathrm{CL}=3 \%, 7 \%$ ), and sedge (Carex spp.; 4\%, CL $=1 \%, 7 \%$ ).

\section{SETTLEMENT PATTERNS}

In 2002, the number of territorial male longspurs observed on our study plots increased between

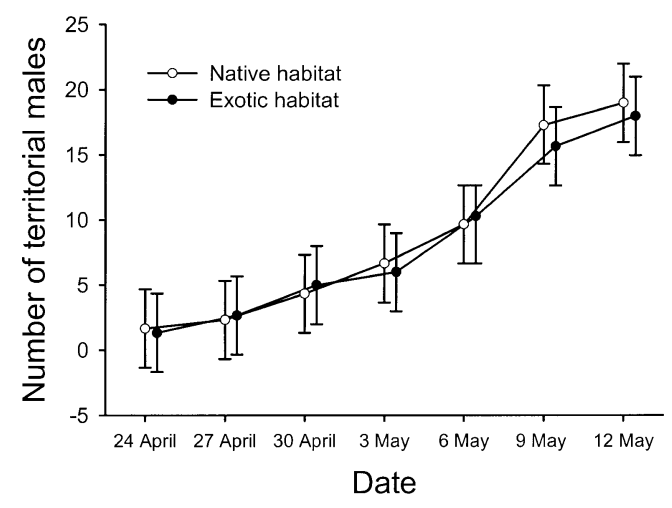

FIGURE 2. Settlement pattern (mean number of territorial males $\pm 95 \% \mathrm{CI}$ ) of male Chestnut-collared Longspurs in native and exotic habitat at Medicine Lake National Wildlife Refuge, Montana, 2002.

24 April and 12 May. Settlement patterns did not differ between habitats (Fig. 2).

\section{NESTING DENSITY \\ AND REPRODUCTIVE SUCCESS}

During the course of the study, we located and monitored 301 longspur nests; 167 on native plots and 134 on exotic plots. Considering only first nesting attempts (initiated before 1 June of each year), the densities of nesting pairs in native and exotic habitat were 1.8 pairs per ha $(\mathrm{CL}$ $=1.7,1.9)$ and 1.2 pairs per ha $(\mathrm{CL}=0.6,1.8)$, respectively.

The phenology of nesting was similar in both habitats (Fig. 1). Considering only nests in which clutch size was known with certainty, the mean clutch size in both habitats was 4.0 eggs (native, $\mathrm{CL}=3.8,4.1, n=116$; exotic, $\mathrm{CL}=$ $3.8,4.1, n=98$ ), and the modal clutch size was 4 eggs. Apparent nesting success was higher in the native habitat (Table 1), and predation was by far the most significant cause of nest failure in both habitats.

Our global model of nest survival fit the data well ( $\left.\chi^{2}=3.3, P=0.92\right)$. Only two of the models in our candidate set received substantial support (Table 2). The best-fitting model contained all variables except for nest initiation date; the next best model, the global model, provided a marginally better fit due to the inclusion of an effect of nest initiation date but had a similar $\mathrm{AIC}_{c}$ value due to the penalty for the additional parameter (Table 2). The Akaike weights strongly suggest (summed weights $=0.96$ ) that one of these two models is indeed the best model for 
TABLE 1. Outcome of nesting attempts in 2001 and 2002 for Chestnut-collared Longspurs breeding in native and exotic habitats at Medicine Lake National Wildlife Refuge, Montana. Data are presented as number of nests with the percentage of nests in parentheses.

\begin{tabular}{lccccccc}
\hline \hline & \multicolumn{7}{c}{ Nest fate } \\
\cline { 2 - 8 } Habitat & Successful & $\begin{array}{c}\text { Abandoned, } \\
\text { unknown } \\
\text { cause }\end{array}$ & $\begin{array}{c}\text { Abandoned, } \\
\text { research } \\
\text { activity }\end{array}$ & Predation & $\begin{array}{c}\text { Failed due } \\
\text { to adult } \\
\text { mortality }\end{array}$ & $\begin{array}{c}\text { Failed due } \\
\text { to weather }\end{array}$ & $\begin{array}{c}\text { Failed due } \\
\text { to cowbird } \\
\text { parasitism }\end{array}$ \\
\hline Native & $80(47.9)$ & $6(3.6)$ & $1(0.6)$ & $70(41.9)$ & 0.0 & $5(3.0)$ & $5(3.0)$ \\
Exotic & $55(41.0)$ & $4(2.9)$ & $1(0.7)$ & $66(49.3)$ & $1(0.7)$ & $4(2.9)$ & $3(2.2)$ \\
\hline
\end{tabular}

the data. The weight of support for the best fitting model is strong relative to the global model. Ultimately, selecting between the two top models is relatively unimportant as they produce nearly identical parameter estimates (all $\beta$ from the two models are within 0.002 of one another). Nonetheless, for the purpose of estimating daily nest survival, we accepted $S_{\text {habitat+year+clutch size+nest }}$ age as the best-fitting model because it had the lowest $\mathrm{AIC}_{c}$ value, it received strong support from Akaike weights, and it was more parsimonious in excluding the relatively weak and variable effect of nest initiation date. However, we acknowledge model-selection uncertainty in our parameter estimates.

The logistic regression equation for the best model was:

TABLE 2. Summary of Akaike's Information Criterion $\left(\mathrm{AIC}_{c}\right)$ values for candidate models explaining nest survival of Chestnut-collared Longspurs at Medicine Lake National Wildlife Refuge, Montana, 20002001. $K$ is the number of parameters estimated by the model, $\Delta \mathrm{AIC}_{c}$ is the difference between a given model and the model with the lowest $\mathrm{AIC}_{c}$ score a and $\mathrm{AIC}_{c}$ weight reflects the relative support for each model.

\begin{tabular}{lccc}
\hline \multicolumn{1}{c}{ Model } & $k$ & $\Delta \mathrm{AIC}_{c}$ & $\begin{array}{c}\mathrm{AIC}_{c} \\
\text { weight }\end{array}$ \\
\hline$S_{\text {habitat+year+clutch size+nest age }}$ & 5 & 0 & 0.67 \\
$S_{\text {global }}$ & 6 & 1.7 & 0.29 \\
$S_{\text {habitat+year+nest age }}$ & 4 & 5.4 & 0.05 \\
$S_{\text {habitat+nest age }}$ & 3 & 22.9 & 0 \\
$S_{\text {habitat } \times \text { nest age }}$ & 3 & 27.9 & 0 \\
$S_{\text {habitat+year+start date+clutch size }}$ & 5 & 30.3 & 0 \\
$S_{\text {nest age }}$ & 2 & 34.1 & 0 \\
$S_{\text {habitat+year+start date }}$ & 4 & 34.6 & 0 \\
$S_{\text {year+habitat } \times \text { start date }}$ & 4 & 35.0 & 0 \\
$S_{\text {year+habitat }}$ & 3 & 67.4 & 0 \\
$S_{\text {year }}$ & 2 & 67.7 & 0 \\
$S_{\text {habitat } \times \text { year }}$ & 3 & 68.4 & 0 \\
$S_{\text {start date }}$ & 2 & 72.4 & 0 \\
$S_{\text {habitat }}$ & 2 & 94.7 & 0 \\
$S_{\text {(constant) }}$ & 1 & 104.0 & 0 \\
\hline
\end{tabular}

a The lowest $\mathrm{AIC}_{c}$ score was 1984.2.

$$
\begin{aligned}
\operatorname{Logit}\left(\hat{S}_{i}\right)= & 3.20-0.18(\text { habitat }) \\
& +0.0001(\text { year })+0.27(\text { clutch size }) \\
& -0.04(\text { nest age })
\end{aligned}
$$

Solving this equation by incorporating values for the selected covariates reveals decreased daily nest survival in the exotic habitat, increased daily nest survival in nests with larger clutches, and decreased daily nest survival as the nest aged (Fig. 3; the effect of year was negligible and ignored for purposes of this figure).

Although the estimates of $\beta$ and associated standard errors reveal the relative strength and direction of each effect, converting these values to odds ratios and $95 \%$ confidence intervals allows additional interpretation regarding the size of effects. Clutch size had the strongest effect on nest success, with each additional egg producing a $30 \%$ increase in the odds of a nest surviving a given day (odds ratio $=1.3, \mathrm{CL}=1.1$, 1.6). The odds of daily survival decreased $4 \%$ per day over the course of the nesting period (odds ratio $=0.96, \mathrm{CL}=0.95,0.97$ ). Finally, the odds of daily nest survival were $17 \%$ greater in native habitat than in exotic habitat (odds ratio $=0.83, \mathrm{CL}=0.72,0.96$ ). The odds of a year effect or an effect of date of nest initiation did not differ from that expected by random chance alone.

The average number of young fledged per nest was significantly lower in the exotic habitat (native: 1.6 young per nest; exotic $=1.0$ young per nest; CL of the difference $=0.08,0.89$ ) as a consequence of higher nest predation and decreased likelihood of successful nesting. This difference is not a result of differences in clutch size or in the extent of partial nest losses: the average number of young fledged from a successful nest was similar in both habitats (native: 2.2 young, $\mathrm{CL}=1.5,2.9$; exotic: 2.4 young, $\mathrm{CL}$ $=1.2,3.6$ ). 


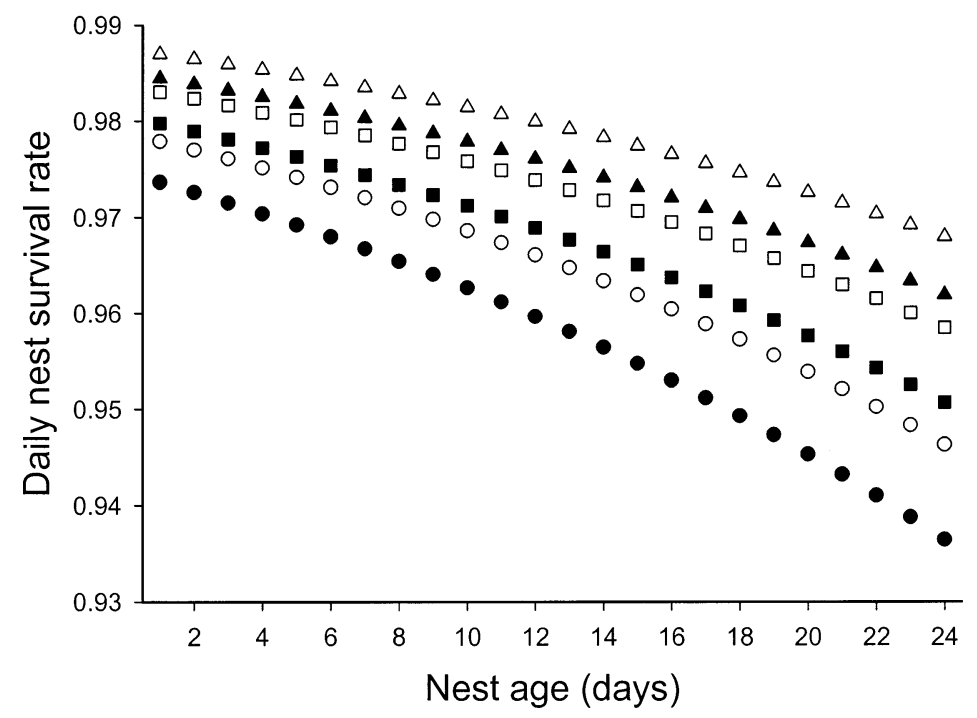

FIGURE 3. Predicted rate of nest success (calculated from the logistic regression equation from the best model) for nests with clutch size 3 (circles), 4 (squares), and 5 (triangles) initiated on day $x$ for Chestnut-collared Longspurs in native (unfilled) and exotic (filled) habitat at Medicine Lake National Wildlife Refuge, 2001-2002.

\section{NESTLING GROWTH RATE}

The logistic curve described nestling growth accurately (mass, $r^{2}=0.85$; tarsus, $r^{2}=0.81$; primaries, $r^{2}=0.89$; all $P<0.001$ ). Nestling longspurs gained mass at a similar rate in 2001 and $2002(P=0.57$ for year effect on mass gain), and therefore data were pooled among years for subsequent analyses. Nestlings in the exotic habitat gained mass at a slower rate $\left(F_{1,5}=12.7, P\right.$ $=0.02$; Fig. 4) and fledged at a smaller mass (native: $14.2 \mathrm{~g}, \mathrm{CL}=13.4,14.9$; exotic: $12.9 \mathrm{~g}$,

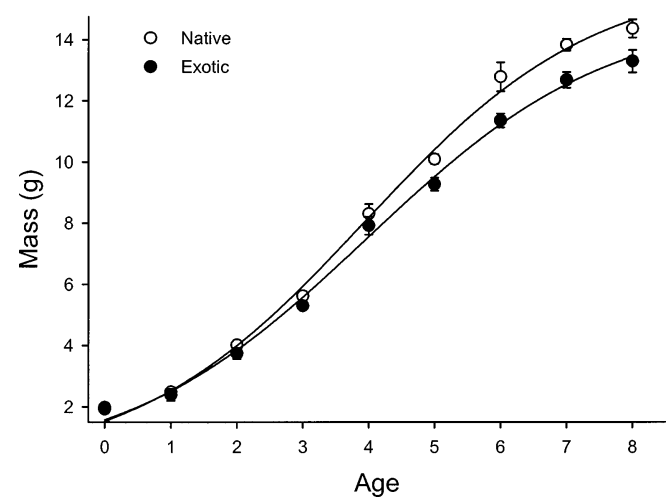

FIGURE 4. Rate of mass gain for Chestnut-collared Longspur nestlings in native and exotic habitat at Medicine Lake National Wildlife Refuge, Montana, 20012002. Logistic curve is shown, and points are mean \pm SE.
$\left.\mathrm{CL}=11.9,13.9 ; F_{1.5}=9.1, P=0.03\right)$. In addition, nestlings in the exotic habitat took one day longer to fledge (native: 8.7 days, $\mathrm{CL}=8.0$, 9.4; exotic: 9.8 days, $\mathrm{CL}=9.1,10.6 ; F_{1,9}=6.0$, $P=0.03)$. Growth rates of tarsi $\left(F_{1,5}=0.3, P\right.$ $=0.58)$ and the outermost primary feather $\left(F_{1,5}\right.$ $=1.1, P=0.35$ ) were similar in both habitats.

\section{DISCUSSION}

Conservation of grassland bird populations depends upon the identification of habitat conditions that promote successful reproduction and survival, but such data are largely lacking. Many studies have addressed the effects of habitat fragmentation on grassland bird populations (Johnson and Temple 1990, Herkert 1994, Winter and Faaborg 1999, Winter et al. 2000, Herkert et al. 2003), but far fewer have examined how changes in the structure or composition of vegetation within a patch influence habitat quality. Land managers cannot readily control the spatial arrangement of habitat patches within a landscape, but they can, to some extent, control conditions within habitat patches. Thus, estimation of habitat-specific demographic rates is of great importance not only in understanding the causes of population declines in grassland birds, but also in facilitating action to reverse them.

In this study, we showed that reproductive success of Chestnut-collared Longspurs was 
lower in monocultures of crested wheatgrass, a species introduced from Asia, than in native prairie. First, odds of a nest in native prairie surviving a given day were approximately $17 \%$ higher than in the exotic habitat, due primarily to differences between habitats in the intensity of nest predation. As a result of lower predation in the native habitat, the average number of young produced per nest was significantly higher in native prairie. Second, we also found that nestling longspurs in the exotic habitat gained mass more slowly and reached a smaller final mass than did nestlings in the native habitat. Retarded growth rate also led to longer nestling periods in the exotic habitat. Habitat-specific growth rates generally reflect differences in environmental quality (Quinney et al. 1986, McCarty and Winkler 1999) and the variation in growth that we observed may have important implications for offspring fitness. Not only does slow growth extend the period of vulnerability to nest predators, as we have shown, but the smaller mass achieved by nestlings in the exotic habitat may reduce future survival (Perrins 1965, Garnett 1981, Davies 1986, Magrath 1991). Mass at fledging for longspurs in the native habitat was approximately $9 \%$ greater than in the exotic habitat; in studies of other songbirds, differences of this magnitude produced a nearly two-fold change in apparent survival (Magrath 1991) and recruitment rate (GebhardtHenrich and Richner 1998).

Despite achieving lower reproductive success in the exotic habitat, we found no evidence that longspurs preferred to nest in the native habitat. They nested at similar densities in both habitats, and individuals did not appear to differentiate between the two habitats when establishing breeding territories in the spring. Birds can use a variety of cues when selecting breeding habitat (Hilden 1965, Boulinier et al. 1996, Forsman et al. 1998) but may often rely on vegetation conditions at the time of settling to predict habitat quality (Badyaev 1995). Although fields of crested wheatgrass differ from patches of native prairie in a number of ways, the two habitats are broadly similar in structure and appearance, thus differentiating exotic from native habitat may be difficult for settling individuals. Furthermore, crested wheatgrass begins growing earlier in the year than most of the native grasses, and the new, green growth may be attractive to long- spurs prospecting for a nesting site (Schmidt and Whelan 1999, Remes 2003)

Nest age and clutch size influenced daily nest survival rate and nesting success independently of habitat. The odds of daily survival declined $4 \%$ per day, which may be a result of the increased conspicuousness of nests containing nestlings, either due to properties of the nestlings themselves (e.g., begging calls that attract predators; Briskie et al. 1999) or due to the increased activity as parents visit the nest to provide food (Martin et al. 2000).

Clutch size had the strongest effect on nest success: each additional egg produced a $31 \%$ increase in the odds that a nest survived a given day. Thus, the odds of daily survival for a clutch of five eggs were approximately $71 \%$ greater than for a clutch of three eggs. Initially, we included clutch size as a means to examine the importance of individual heterogeneity for nest survival rates, as many studies have shown that clutch size reflects the quality or condition of females (Silverin 1981, Askenmo 1982, Martin 1987, Slagsvold and Lifjeld 1990, Schluter and Gustafsson 1993, Bolton et al. 1993). Individual condition or quality might influence predation risk if low quality females made poor decisions about where to place nests. Indeed, our results, which show a strong, positive effect of clutch size on daily nest survival, suggest that female condition, as measured by clutch size, is somehow connected to predation risk. Clutch size was not directly linked to predation risk. The positive effect of clutch size is not confounded with the difference between habitats in the likelihood of nest success; clutch size was the same in both habitats. The results of including clutch size as a variable clearly demonstrate the importance of considering individual heterogeneity in studies of nesting success.

Our results have important implications for the conservation of grassland birds. First, they show that changes to the structure and species composition of vegetation within patches of breeding habitat can affect the reproductive success of grassland birds. The effects of habitat loss and fragmentation on the distribution, abundance, and reproductive success of grassland birds are well described; based on the results presented here and elsewhere (Dobkin 1994, Knick et al. 2003), degradation of breeding habitat also appears to play a significant role in the widespread decline of grassland bird popula- 
tions. Second, they add to the growing body of evidence that the introduction and spread of exotic plants can have adverse fitness consequences for native animals (Schmidt and Whelan 1999, Remes 2003), and suggest that the planting of exotic grasses, such as for forage production or erosion control (Byers 2004) is likely to have negative effects on grassland bird populations. Finally, longspurs did not appear to differentiate between native and exotic habitats, despite achieving low reproductive success in the exotic habitat. Thus, future conservation efforts should emphasize the restoration, maintenance, and protection of native prairie. Across parts of North America extensive tracts of native prairie are nonexistent and the only habitats for grassland birds in these areas are old agricultural fields converted to perennial grassland under the Conservation Reserve Program. Traditionally, most of the acreage in the Conservation Reserve Program was planted to exotic species, such as crested wheatgrass, but our results suggest that the Conservation Reserve Program will be of greater benefit in creating high-quality habitat for wildlife if native grasses are emphasized in plantings. Although we have much to learn about the causes of reduced reproductive success in exotic habitats, conservation efforts targeted at grassland birds must begin to consider not only the amount and arrangement of habitat at the landscape scale, but also the conditions within habitat patches.

\section{ACKNOWLEDGMENTS}

Significant funding was provided by the U.S. Prairie Pothole Joint Venture. Support was also provided by a Sigma Xi Grant-in-Aid of Research to JDL, the Wildlife Biology program at the University of Montana, and NSF grant DEB-9707598 to T.E.M. Thanks to Joe Ball for his support and contributions to this project. The staff of Medicine Lake National Wildlife Refuge, especially Beth Madden and Shannon Swanson, provided invaluable assistance and guidance during the completion of fieldwork. Thanks also to Terry Shaffer for his willingness to help us understand and implement the nest survival analyses. Thank you to Victoria Lloyd and Gary Slater for support during the preparation of this manuscript, and to David Dobkin and two anonymous reviewers for assistance in improving the quality of this manuscript. Finally, thank you to all of the people who helped to collect the data presented here.

\section{LITERATURE CITED}

AKAIKE, H. 1973. Information theory and an extension of the maximum likelihood principle, p. 267-281.
In B. N. Petran and F. Csaki [EDS.], International symposium on information theory. Akademiai Kiado, Budapest, Hungary.

Anderson, D. R., K. P. Burnham, And W. L. ThompSON. 2000. Null hypothesis testing: problems, prevalence, and an alternative. Journal of Wildlife Management 64:912-923.

Askenmo, C. 1982. Clutch size flexibility in the Pied Flycatcher. Ardea 70:189-196.

BADYAEV, A. V. 1995. Nesting habitat and nesting success of eastern Wild Turkeys in the Arkansas Ozark highlands. Condor 97:221-232.

Bolton, M., P. Monaghan, and D. C. Houston. 1993. Proximate determination of clutch size in Lesser Black-backed Gulls: the roles of food supply and body condition. Canadian Journal of Zoology 71: 273-279.

Boulinier, T., E. Danchin, J.-Y. Monnat, C. DoutreLANT, AND B. CADIOU. 1996. Timing of prospecting and the value of information in a colonial breeding bird. Journal of Avian Biology 27:252256.

Bragg, T. B., And A. A. Steuter. 1995. Mixed prairie of the North American Great Plains. Transactions of the North American Wildlife and Natural Resources Conference 60:335-348.

Briskie, J. V., P. R. Martin, And T. E. Martin. 1999. Nest predation and the evolution of nestling begging calls. Proceedings of the Royal Society of London Series B 2666:2153-2159.

Burnham, K. P., And D. R. Anderson. 1998. Model selection and inference: a practical informationtheoretic approach. Springer-Verlag, New York.

Burnham, K. P., And D. R. Anderson. 2001. Kullnack-Leibler information as a basis for strong inference in ecological studies. Wildlife Research 28:111-119.

BYERS, J. L. 2004. Postfire seeding for erosion control: effectiveness and impacts on native plant communities. Conservation Biology 18:947-956.

Christian, J. M., AND S. D. Wilson. 1999. Long-term ecosystem impacts of an introduced grass in the northern Great Plains. Ecology 80:2397-2407.

Davies, H. T. O., I. K. Crombie, and M. Tavakoli. 1998. When can odds ratios mislead? British Medical Journal 316:989-991.

DAVIES, N. B. 1986. Reproductive success of Dunnocks, Prunella modularis, in a variable mating system. I. Factors influencing provisioning rate, nestling weight and fledgling success. Journal of Animal Ecology 55:123-138.

Dobkin, D. S. 1994. Conservation and management of Neotropical migrant landbirds in the Northern Rockies and Great Plains. University of Idaho Press, Moscow, ID.

Forsman, J. T., M. MonkKonen, P. Helle, and J. InKEROINEN. 1998. Heterospecific attraction and food resources in migrants' breeding patch selection in northern boreal forest. Oecologia 115:278286.

GARnetT, M. C. 1981. Body size, its heritability and influence on juvenile survival among Great Tits, Parus major. Ibis 123:31-41. 
Gebhardt-Henrich, S., And H. Richner. 1998. Causes of growth variation and its consequences for fitness, p. 324-339. In J. M. Starck and R. E. Ricklefs [EDS.], Avian growth and development. Oxford University Press, New York.

Gotmark, F. 1992. The effects of investigator disturbance on nesting birds. Current Ornithology 9:63104.

Greenwood, R. J., A. B. Sargeant, D. H. Johnson, L. M. Cowardin, AND T. L. Shaffer. 1995. Factors associated with duck nest success in the prairie pothole region of Canada. Wildlife Monographs 128:1-57.

Hein, E. W., AND W. S. HeIn. 1996. Effect of flagging on predation of artificial duck nests. Journal of Field Ornithology 67:604-611.

Herkert, J. R., D. L. Reinking, D. A. Wiedenfeld, M. Winter, J. L. Zimmerman, W. E. Jensen, E. J. Finck, R. R. Koford, D. H. Wolfe, S. K. SHERRod, M. A. Jenkins, J. FAabord, and S. K. RobINSON. 2003. Effects of prairie fragmentation on the nest success of breeding birds in the midcontinental United States. Conservation Biology 17: 587-594.

HeRKERT, J. R. 1994. The effects of habitat fragmentation on midwestern grassland bird communities. Ecological Applications 4:461-471.

Hilden, O. 1965. Habitat selection in birds. Annales Zoologici Fennici 2:53-75.

Hill, D. P., AND L. K. Gould. 1993. Chestnut-collared Longspur, p. 1-19. In A. Poole and F. Gill [EDS.], The Birds of North America, No. 288. The Academy of Natural Sciences, Philadelphia, PA, and The American Ornithologists' Union, Washington, DC.

HоснаснкA, W. 1990. Seasonal decline in reproductive performance of Song Sparrows. Ecology 71: 1279-1288.

Hosmer, D. W., JR., AND S. Lemeshow. 1989. Applied logistic regression. John Wiley and Sons, New York.

Johnson, R. G., And S. A. Temple. 1990. Nest predation and brood parasitism of tallgrass prairie birds. Journal of Wildlife Management 54:106111.

KantRud, H. A. 1981. Grazing intensity effects on the breeding avifauna of North Dakota native grasslands. Canadian Field Naturalist 95:404-417.

Klopatek, J. M., R. J. Olson, C. J. Emerson, and J. L. JoNESS. 1979. Land-use conflicts with natural vegetation in the United States. Environmental Conservation 6:191-199.

Knick, S. T., D. S. Dobkin, J. T. Rotenberry, M. A. Schroeder, W. M. Vander Haegen, And C. VAN RIPER, III. 2003. Teetering on the edge or too late? Conservation and research issues for avifauna of sagebrush habitats. Condor 105:611-634.

KNOPF, F. L. 1994. Avian assemblages on altered grasslands. Studies in Avian Biology 15:247-257.

KunZ, C., AND J. EkMan. 2000. Genetic and environmental components of growth in nestling Blue Tits (Parus caeruleus). Journal of Evolutionary Biology 13:199-212.
LesicA, P., And T. H. DeLuCA. 1996. Long-term harmful effects of crested wheatgrass on Great Plains grassland ecosystems. Journal of Soil and Water Conservation 51:408-409.

LIMA, S. L. 1987. Clutch size in birds: a predation perspective. Ecology 68:1062-1070.

LOKEMOEN, J. T., AND R. R. KoFORD. 1996. Using candlers to determine the incubation stage of passerine eggs. Journal of Field Ornithology 67:660668.

Madden, E. M., A. J. Hansen, and R. K. Murphy. 1999. Influence of prescribed fire history on habitat and abundance of passerine birds in northern mixed-grass prairie. Canadian Field Naturalist 113:627-640.

Madden, E. M., R. K. Murphy, A. J. Hansen, and L. MurRAY. 2000. Models for guiding management of prairie bird habitat in northwestern North Dakota. American Midland Naturalist 144:377-392.

Magrath, R. D. 1991. Nestling weight and juvenile survival in the Blackbird, Turdus merula. Journal of Animal Ecology 60:335-351.

Martin, T. E. 1987. Food as a limit on breeding birds: a life-history perspective. Annual Review of Ecology and Systematics 18:453-487.

MARTIN, T. E. 1992a. Breeding season productivity: what are the appropriate habitat features for management?, p. 455-473. In J. M. Hagan and D. W. Johnston [EDS.], Ecology and conservation of Neotropical migrant land birds. Smithsonian Institution Press, Washington, DC.

Martin, T. E. 1992b. Interaction of nest predation and food limitation in reproductive strategies. Current Ornithology 9:163-197.

Martin, T. E., AND J. J. Roper. 1988. Nest predation and nest site selection in a western population of the Hermit Thrush. Condor 90:51-57.

Martin, T. E., J. Scott, And C. Menges. 2000. Nest predation increases with parental activity: separating nest site and parental activity effects. Proceedings of the Royal Society of London Series B 267:2287-2293.

McCARTY, J. P., AND D. W. WinkLer. 1999. Relative importance of environmental variables in determining the growth of nestling Tree Swallows Tachycineata bicolor. Ibis 141:286-296.

MERILA, J., AND J. D. FRY. 1998. Genetic variation and causes of genotype-environment interaction in the body size of Blue Tit (Parus caeruleus). Genetics 148:1233-1244.

Mermoz, M. E., ANd J. C. Reboreda. 1998. Nesting success in Brown-and-Yellow Marshbirds: effects of timing, nest site, and brood parasitism. Auk 115:871-878.

Nilsson, J. A. 1989. Causes and consequences of natal dispersal in the Marsh Tit (Parus palustris). Journal of Animal Ecology 58:619-636.

Noss, R., E. T. LaRoe, And J. M. Soctt. 1995. Endangered ecosystems of the United States: a preliminary assessment of loss and degradation. Report 0611-R-01. National Biological Service, Washington, DC.

Pampush, G. J., And R. G. Anthony. 1993. Nest success, habitat utilization and nest-site selection of 
Long-Billed Curlews in the Columbia Basin, Oregon. Condor 95:957-967.

Peak, R. G., F. R. Thompson III, and T. L. Shaffer. 2004. Factors affecting songbird nest survival in riparian forests in a midwestern agricultural landscape. Auk 121:727-737.

Perrins, C. M. 1965. Population fluctuations and clutch size in the Great Tit, Parus major L. Journal of Animal Ecology 34:601-647.

Peterjohn, B. G., And J. R. SAuer. 1999. Population status of North American grassland birds from the North American Breeding Bird Survey, 19661996. Studies in Avian Biology 19:27-44.

Price, T., AND L. Liou. 1989. Selection on clutch size in birds. American Naturalist 134:950-959.

PYLYPEC, B. 1991. Impacts of fire on bird populations in a fescue prairie. Canadian Field Naturalist 105: 346-349.

Quinney, T. E., D. J. T. Hussell, And C. D. Ankney. 1986. Sources of variation in the growth of Tree Swallows. Auk 103:389-400.

Remes, V. 2003. Effects of exotic habitat on nesting success, territory density, and settlement patterns in the Blackcap (Sylvia atricapilla). Conservation Biology 17:1127-1133.

RichARDSON, R. E., AND T. L. HANSON. 1977. Soil survey of Sheridan County, Montana. U.S. Department of Agriculture, Soil Conservation Service, Washington, DC.

RicKLEFS, R. E. 1969. An analysis of nesting mortality in birds. Smithsonian Contributions in Zoology 9: $1-48$.

Ricklefs, R. E. 1983. Avian postnatal development, p. 1-83. In D. S. Farner, J. R. King, and K. C. Parkes [EDS.], Avian biology. Academic Press, New York.

SAS InstituTE. 1999. SAS/STAT user's guide. Version 8. SAS Institute Inc., Cary, NC.

Scheiman, D. M., E. K. Bollinger, And D. H. JohnSON. 2003. Effects of leafy spurge infestation on grassland birds. Journal of Wildlife Management 67:115-121.

Schluter, D., AND L. Gustafsson. 1993. Maternal inheritance of condition and clutch size in the Collared Flycatcher. Evolution 47:658-667.

Schmidt, K. A., AND C. J. Whelan. 1999. Effects of exotic Lonicera and Rhamnus on songbird nest predation. Conservation Biology 13:1502-1506.

SHAFFER, T. L. 2004. A unified approach to analyzing nest success. Auk 121:526-540.

Silverin, B. 1981. Reproductive effort, as expressed in body and organ weights, in the Pied Flycatcher. Ornis Scandinavica 12:113-139.

SkUTCH, A. F. 1949. Do tropical birds rear as many young as they can nourish? Ibis 91:430-455.

Slagsvold, T., AND J. T. LIFJELD. 1988. Ultimate adjustment of clutch size to parental feeding capacity in a passerine bird. Ecology 69:1918-1922.

Slagsvold, T., AND J. T. LIFJELD. 1990. Influence of male and female quality on clutch size in tits $(\mathrm{Pa}$ rus spp.). Ecology 71:1258-1266.

VAN Horne, B. 1983. Density as a misleading indicator of habitat quality. Journal of Wildlife Management 43:893-901.

Vickery, P. D., AND J. R. Herkert. 2001. Recent advances in grassland bird research: where do we go from here? Auk 118:11-15.

White, G. C., And K. P. Burnham. 1999. Program MARK: survival estimation from populations of marked animals. Bird Study 46:120-139.

Wilson, S. D., AND J. W. BelChER. 1989. Plant and bird communities of native prairie and introduced Eurasian vegetation in Manitoba, Canada. Conservation Biology 3:39-44.

Winter, M., AND J. FAaborg. 1999. Patterns of area sensitivity in grassland-nesting birds. Conservation Biology 13:1424-1436.

Winter, M., D. H. Johnson, AND J. FAABORG. 2000. Evidence for edge effects on multiple levels in tallgrass prairie. Condor 102:256-266. 